\title{
RELEVANSI SIKAP PLURALIS YESUS DALAM INJIL LUKAS
}

\section{Marlen Tineke Alakaman}

\begin{abstract}
In the context of diversity, nonetheless there is an attitude that contrary to that reality. The diversity of the community and Indonesia in particular Maluku, which is composed of various religious, ethnic and racial diversity issues there are also show it. The exclusive attitude, often conflict and dissension that use "religious dress", an action of terrorism, the destruction and burning of places of worship, and means of mutual suspicious suspects between religious (Islam and Christianity) simply proves that the attitude of the pluralism is expected be an option within the context of society in Indonesia and the Moluccas in particular is far from what was expected. Learn from Jesus ' figure who also live in the context of pluralism, original but a Jew himself always depicted as being in conflict with the mood of the leaders of the Jewish religion. The practice of the life of Jesus as picture by the book of Luke is interesting in the context of diversity in Indonesia and Moluccas. By Luke, Jesus demonstrated pluralism attitude is as follows: Jesus sided with the poor people Women companions of Jesus, Jesus the friend of publicans and sinners. The concrete which distinguishes the book of Gospels with Luke's other love story is the enemy and the Samaritans are generous ago according to the author, Jesus teaches a new attitude pattern, the pattern of pluralism attitude that acts indiscriminately, until the enemy though.
\end{abstract}

Keyword:pluralisand gospel of Luke

\begin{abstract}
Abstrak
Dalam konteks keberagaman, tetap saja ada sikap yang bertentangan dengan kenyataan itu.Keragaman masyarakat Indonesia dan Maluku khususnya terdiri dari berbagai agama, etnis dan ras juga menunjukkan terdapatnya persoalan keberagaman itu. Sikap eksklusif, konflik dan pertikaian yang menggunakan "baju agama", merebaknya aksi-aksi teroris, pengrusakan dan pembakaran sarana dan tempat ibadah, sikap saling curiga antar umat beragama (Islam dan Kristen) cukup membuktikan bahwa sikap pluralis yang diharapkan menjadi pilihan dalam konteks bermasyarakat di Indonesia dan Maluku khususnya masih jauh dari apa yang diharapkan. Belajar dari tokoh Yesus yang juga hidup dalam konteks kemajemukan, seorang Yahudi asli tetapi diri-Nya senantiasa dilukiskan sebagai yang berada didalam suasana konflik dengan para pemuka agama Yahudi.Praktek hidup Yesus sebagaimana yang dipotretkan oleh Kitab Lukas menjadi hal yang menarik dalam konteks keberagaman di Indonesia dan Maluku.Menurut Lukas, sikap pluralis yang ditunjukkan Yesus yakni Yesus berpihak pada orang-orang miskin, Yesus sahabat kaum perempuan, Yesus sahabat pemungut cukai dan orang berdosa. Konkritnya yang membedakan kitab Lukas dengan Kitab Injil lainnya ialah cerita mengasihi musuh dan orang Samaria yang murah hati yang bagi penulis, Yesus mengajarkan suatu pola sikap baru, pola sikap yang pluralis yang bertindak tanpa pandang bulu, sampai pada musuh sekalipun.
\end{abstract}

Kata Kunci :pluralis dan Injil Lukas 


\section{PENDAHULUAN}

Pluralisme dalam masyarakat adalah fakta yang tidak dapat disangkali keberadaannya, khususnya di tengah kemajemukan budaya dan agama di Indonesia.Kondisi masyarakat Indonesia yang plural baik dari aspek suku, ras, agama serta status sosial memberikan kontribusi sekaligus persoalan sosial yang luar biasa terhadap perkembangan dan dinamika kehidupan sosial dalam masyarakat.Kondisi dan situasi seperti ini merupakan suatu kewajaran sejauh perbedaan-perbedaan ini disadari keberadaannya dan dihayati.Namun ketika perbedaan-perbedaan tersebut mengemuka dan kemudian menjadi sebuah ancaman untuk kerukunan hidup, maka perbedaan tersebut menjadi masalah yang harus diselesaikan.

Salah satu sikap yang menonjol dari kenyataan kehidupan beragama adalah menonjolnya sikap eksklusif.Pandangan eksklusif beranggapan bahwa keselamatan dan kebenaran hanya ada pada agamanya sendiri, sedangkan diluar dirinya tidak ada lagi keselamatan dan kebenaran. Ungkapan extra ecclesiam nula salus, (di luar gereja tidak ada keselamatan), adalah contoh nyata sikap ini. ${ }^{1}$

Pendekatan ini semakin didukung dengan penggunaan ayat-ayat dalam Alkitab yang sifatnya eksklusif, seperti contoh Yohanes 14:6 yang berbunyi demikian: "Akulah jalan kebenaran dan hidup. Tidak ada seorang pun yang datang kepada Bapa, kalau tidak melalui Aku." Atau juga Matius 28:19-20 yang berbunyi: karena itu pergilah, jadikanlah semua bangsa murid-Ku dan baptislah mereka dalam nama Bapa dan Anak dan Roh Kudus, dan ajarlah mereka melakukan segala sesuatu yang telah kuperintahkan kepadamu.

Hal ini terasa sangat kuat menguasai cara beriman pemeluk agama di Indonesia, khususnya Islam-Kristen. Di Maluku dan Ambon khususnya, sikap eksklusif ini terjadi sangat mencolok di kalangan orang Kristen dan mengalami perubahan sikap hubungan denominasi gereja setelah konflik. Dimana terhadap agama sendiri dan bahkan denominasi lain, orang cenderung menganggap diri ataupun ajarannya yang benar bahkan saling beradu mulut sampai pada perkelahian. John Hick melihat hal ini sebagai sesuatu yang sangat budayawi, 
dengan pengertian bahwa pemahaman itu terjadi dalam kondisi-kondisi simbolik budaya masyarakat tertentu. Umat Israel (Yahudi) misalnya, meyakini bahwa kebenaran atau yang disebut sebagai the eternal one, atau yang kekal hanya dapat dipahami sebagai Yahweh secara konkrit dalam bentuk Allah Abraham, Allah Ishak, Allah Yakub, sedangkan dalam masyarakat India yang kekal itu dipahami sebagai Syiwa atau Krishna. ${ }^{2}$ Sering terjadinya konflik dan pertikaian yang menggunakan "baju agama", merebaknya aksi-aksi teroris, pengrusakan dan pembakaran sarana dan tempat-tempat ibadah di negara kita, masih saling curigamencurigai antara umat Islam dan Kristen dan agama lainnya, cukup membuktikan dan menunjukkan bahwa sikap pluralis yang diharapkan menjadi pilihan dalam konteks bermasyarakat di Indonesia masih jauh dari yang diharapkan.

Realita kehidupan masyarakat yang dipaparkan di atas, sebenarnya tidak berbeda dengan realita yang dialami oleh komunitas Kristen zaman Yesus Kristus berkarya dimana masyarakat pada waktu itu ditata secara kaku menurut golongangolongan tingkat sosial, dan rasa. Ada tembok pemisah yang didirikan orang, melalui adat dan hak istimewa, untuk meningkatkan kedudukannya menyaingi orang lain. Pada zaman ini pula, tembok pemisah ras malahan lebih kuat, dimana orang Yahudi menolak berhubungan dengan bangsa lain lebih daripada yang diperlukan. ${ }^{3}$ Fenomena tersebut menarik bagi penulis untuk melihat cara hidup yang dipraktikkan Yesus bagi jemaat Kristen mula-mula dan relevansinya saat ini. Hal ini penting dalam rangka membangun kehidupan kekristenan saat ini, dengan menjadikan Yesus Kristus sebagai teladan.

Dalam konteks masyarakat yang dipaparkan di atas, Yesus mencengangkan banyak orang, termasuk murid-Nya sendiri, lebih-lebih di antara para penguasa. Yesus sebagai orang Yahudi, merayakan Sabat di Kapernaum bersama-sama dengan orang Yahudi yang lain ia pergi ke rumah ibadah (Sinagoge) dan menerangkan Kitab Suci kepada mereka. Mereka yang berada dalam sinagoge takjub mendengar pengajaran-Nya, sebab Ia mengajar mereka sebagai orang yang berkuasa, tidak seperti ahli-ahli Taurat. Kesan ini diperkuat oleh konfrontasi Yesus dengan seorang yang sakit, seorang yang kerasukan roh jahat yang 
berteriak (Mark. 1-22-24), selanjutnya Yesus mulai melakukan pelayanan bagi mereka yang membutuhkan pertolongan, mereka yang kesusahan dan yang mengalami penderitaan. Sebut saja anak perempuan Yairus, pemimpin Sinagoge yang sakit berat, perempuan yang sakit pendarahan, telah dua belas tahun lamanya ia menderita. ${ }^{4}$

Bila diperhatikan dengan baik, seringkali keempat penulis Injil melaporkan cara Yesus hadir pada pertemuan-pertemuan sosial. Ia turut merayakan pernikahan di Kana, suatu desa kira-kira lima belas kilometer Utara dari Nazaret. Tidak jarang juga ia mengunjungi teman-teman-Nya di Betania, suatu desa dua setengah kilometer ke Timur dari kota Yerusalem. Hubungan-Nya dengan Marta, Maria dan Lazarus akrab sekali (Luk. 10:41-42). ${ }^{5}$ Yesus juga bergaul dengan sembarangan orang tanpa menghiraukan penggolongan yang lasim dibuat manusia. Ia diterima sebagai tamu oleh seorang Farisi, suatu golongan yang terkemuka dalam masyarakat Yahudi pada waktu itu. Sebagai tamu di rumah siapapun juga, Ia mampu bertindak normal tanpa memperlihatkan perilaku seakan-akan disesuaikan dengan status dan pandangan tuan rumah yang bersangkutan.

Demikian pula Yesus duduk makan pada meja yang sama dengan seorang pemungut cukai, bahkan seorang kepala pemungut cukai. Meskipun Ia tahu betapa tajamnya kecaman-kecaman yang bakal dilontarkan pada diri-Nya. Ia juga bergaul bersama anak-anak, yang jarang sekali terjadi, sebab sikap orang-orang dewasa Yahudi tidak terbuka kepada anak-anak. ${ }^{6}$ Hal ini menunjukkan bahwa Yesus adalah seorang Yahudi tulen atau Yahudi asli, tetapi praktik hidup yang ditampilkan oleh Yesus berbeda dengan yang kebanyakan orang yahudi saat itu. Yesus tidak mau dibatasi.

\section{SIKAP PLURALIS YESUS DALAM INJIL LUKAS}

Dalam penggolongan kitab-kitab Perjanjian Baru, Injil Lukas ada pada penggolongan kitab sejarah (Matius, Markus, Lukas, Yohanes dan Kisah Para Rasul). Kehidupan Yesus hanya terdapat dalam keempat Injil, Matius, Markus, 
Lukas dan Yohanes, meskipun banyak kitab yang dimaksudkan untuk memberikan data-data mengenai kehidupan Yesus yang tidak terekam dalam keempat Injil.

Injil Lukas $^{7}$ adalah kitab pertama ${ }^{8}$ dari kedua kitab yang dialamatkan kepada seorang bernama Teofilus ${ }^{9}$ (Luk 1:1,3; Kis 1:1). Nama ini disapa dengan sebutan Teofilus yang mulia. Gelar "yang mulia" itu menunjuk kepada seorang terkemuka, sebagai cara penyebutan yang penuh hormat ini biasanya digunakan khusus untuk para pejabat tinggi Romawi pada waktu itu. Walaupun nama penulis tidak dicantumkan dalam dua kitab tersebut, kesaksian yang bulat dari kekristenan mula-mula dan bukti kuat dari dalam kitab-kitab itu sendiri menunjukkan bahwa Lukaslah yang menulis kedua kitab itu. ${ }^{10}$ Sebenarnya, tradisi yang menyebutkan Lukas sebagai pengarangnya berkali-kali dikecam. Tetapi di pihak lain ada banyak ahli yang berpendapat bahwa Kitab Injil ini memang ada sangkut-pautnya dengan Lukas, yakni Dokter Lukas yang namanya kita temui dalam beberapa surat Paulus. Dalam Kolose 4:14 tertulis, "salam kepadamu dari tabib Lukas, yang kekasih.” Juga dalam ayat 24 dari suratnya kepada Filemon disebutkan namanya. Dari 2 Timotius 4:11 ternyata bahwa ia pada waktu itu menumpang bersama-sama dengan Paulus di Roma. ${ }^{11}$

Lukas, teman seperjalanan Pekabaran Injil Paulus, adalah seorang dokter, dan memang sering dikemukakan bahwa Injil Lukas dan Kisah Para Rasul menunjukkan pengetahuan khusus tentang bahasa kedokteran, serta perhatian di dalam melakukan diagnose penyakit. Hal ini secara mencolok terlihat dalam cerita bagaimana Yesus menyembuhkan seorang wanita yang mengalami pendarahan yang tidak dapat disembuhkan. Lukas berasal dari Antiokhia di Siria. ${ }^{12}$

Dari pendahuluan (Luk. 1:1-4), Lukas telah dapat mempergunakan sumber-sumber tertulis, yakni Sumber Q. ${ }^{13}$ Ketika Lukas menulis kitabnya, Injil Markus sudah selesai, juga Matius yang menulis kitabnya kira-kira dalam waktu yang sama seperti Lukas telah mempergunakan bahan-bahan Markus itu. Di samping itu, kedua-duanya mengenal juga sumber tertulis yang terutama memuat perkataan Yesus, yang disebutkan Logia (perkataan-perkataan), dan menyelesaikan tulisannya sekitar tahun antara 70 dan $80 \mathrm{M}^{14}$ 
Dalam tulisannya, ia mau memberi keadaan yang sebenarnya tentang Yesus (Luk 1:4). Hal yang diistimewakan Lukas ialah perhatian kepada orang yang menderita, yang miskin, yang "hilang", yang berdosa. Hanya Lukas saja yang membuka bagi kita belas kasihan Yesus terhadap penjahat yang bertobat di kayu salib (Luk 23:40-43). ${ }^{15}$ Perrin juga mengatakan hal yang sama tentang perhatian Lukas, bahwa Lukas memberi perhatian pada orang-orang asing atau orang-orang terbuang, orang miskin, anak-anak dan perempuan, orang Samaria, dan orang bukan Yahudi, oleh karena dalam pemikiran penulis istilah keselamatan itu adalah yang universal. ${ }^{16}$ Sejalan dengan pemikiran ini, Marxsenmengatakan bahwa Lukas menambahkan suatu kelanjutan kepada Injilnya dalam Kisah Para Rasul (Kis. 1:1), adanya suatu kelanjutan yang dipahami dalam cerita dan tujuannya tentang pemberitaan Injil. Menurut Kisah Para Rasul misi Gereja meluas ke Samaria dan daerah-daerah di luar Palestina, bahwa misi yang disampaikan tidaklah bertentangan dengan keyakinan Yahudi. ${ }^{17}$

Perbedaan yang jelas antara orang Yahudi dan bukan Yahudi menjadi kabur dengan kehadiran orang-orang Samaria, yang mendiami wilayah antara Galilea dan Yudea. Mereka mempunyai hubungan yang sangat dekat dengan orang Yahudi dari segi ras, bahasa dan bahkan agama, namun berabad-abad lamanya mereka telah hidup terpisah. Di antara kedua komunitas tersebut telah timbul sikap saling benci. ${ }^{18}$

Jemaat yang digambarkan dalam Injil Lukas adalah jemaat yang tengah menghadapi rupa-rupa persoalan. Pertama, komunitas Lukas sedang mengalami krisis pengharapan akan kedatangan Tuhan (parousia). Diantara mereka ada yang tetap bertekun dalam pengharapan kedatangan Tuhan sementara yang lain sudah mulai lesu imannya dan terus mempertanyakan kapan hari kedatangan Tuhan itu tiba (Lukas 17:8). Injil Lukas sendiri menegaskan bahwa Hari Tuhan pasti akan datang (Lukas 21:8,9b) asalkan Injil telah diberitakan ke seluruh dunia. Dengan demikian, yang menjadi fokus seharusnya bukan pada perhitungan kedatangan Hari Tuhan melainkan pada pemberitaan Injil.

Persoalan kedua adalah banyaknya orang kaya yang sudah menjadi Kristen. Orang-orang kaya ini kemudian menimbulkan masalah didalam jemaat. Mereka 
memiliki watak yang egois dan tamak serta mengabaikan keadaan orang miskin. Karena ketamakan ini, mereka berada pada posisi yang berbahaya dan mereka dapat dengan mudah jatuh dari imannya. Persoalan ketiga adalah mengenai hubungan gereja dan negara. Hubungan keduanya digambarkan oleh Injil Lukas tidaklah saling bermusuhan atau terlibat dalam konflik.

Kerajaan Allah adalah salah satu pokok pemberitaan Yesus (Lukas 4:43; 8:1; 9:11). Ungkapan basileia tou theou (Kerajaan Allah) yang dipakai dalam Injil Lukas menunjuk kepada tindakan Allah dalam sejarah manusia untuk mewujudkan Kerajaan-Nya melalui pelayanan Yesus. Sekalipun Yesus yang digambarkan Lukas sangat menekankan kehadiran kerajaan Allah dalam dunia pada masa kini tetapi tidak berarti Yesus mengabaikan kedatangan Kerajaan Allah yang pada masa mendatang. Pemenuhan Kerajaan Allah yang penuh kemuliaan pada masa depan tetap dinantikan.

Kenyataan bahwa tulisan Lukas ini ditujukan kepada orang-orang bukan Yahudi tampak dengan jelas di seluruh kitab Injil ini. Dalam tulisannya, Yesus dengan jelas terlihat sebagai Juruselamat yang ilahi-insani yang menawarkan pengampunan dan penebusan secara bebas kepada semua orang, tidak memilih dan tergantung pada suku, ras, golongan, jenis kelamin, dan bahkan bangsa.

Kemampuan sastra Lukas yang tinggi tercermin jelas dalam caranya mengembangkan adegan-adegan tertentu yang menimbulkan respons emosional dan peribadahan pembaca Injilnya. Cerita pertama adalah tentang penyembuhan hamba seorang perwira. Cerita ini juga dikemukakan Matius dan ditempatkan pada posisi yang sama, yaitu sesudah khotbah (Mat. 8:5-13). Namun ada perbedaan yang mencolok antara versi Matius dan versi Lukas. Pertama, berbeda dengan Matius yang memasukkan beberapa perkataan yesus, Lukas menyimpan perkataan-perkataan Yesus tersebut untuk kesempatan berikutnya. Selain itu, dalam versi Lukas, perwira tersebut tidak berhadapan muka dengan Yesus tetapi menggunakan perantara.

Sikap pluralis Yesus yang ditonjolkan dalam Injil ini dapat kita lihat pada awal Yesus memulai karya-Nya di Galilea yang dimulai dari Nazareth. ${ }^{19}$ Misalnya, menyampaikan kabar baik kepada orang-orang miskin, memberikan pembebasan 
bagi orang-orang tawanan (Pasal 4:16-20). Cerita ini dimulai ketika Yesus memberi tanda bahwa Ia mau melakukan pembacaan dari Kitab-Kitab para nabi, diberikan kepada-Nya gulungan Kitab Yesaya. Ia membuka gulungan itu sampai Ia menemui Yesaya 61:1-2 yang dikutip dalam ayat 18-19 ini (menurut terjemahan yang agak bebas dalam bahasa Yunani, sedang barangkali juga disisipkan suatu kata dari Yes. 56:6). Dalam Yesaya 61 itu dibicarakan tentang Hamba Tuhan Allah yang telah menerima Roh Allah dan dengan demikian “diurapi” (ditahbiskan) oleh Allah untuk jabatannya (untuk pekerjaan Allah itu dipakai dalam bahasa Yunani kata kerja "chria”, yang daripadanya dibentuk kata "Christos" berarti Kristus atau yang diurapi).

Dalam cerita ini dikatakan bahwa "kabar baik" (ayat. 18) mengenai keselamatan itu (Yun.euangelion berartiInjil) terutama akan menjadi kabar baik untuk orang-orang miskin, yakni rakyat biasa atau orang banyak, yang oleh orangorang berkuasa dan pemimpin-pemimpin agama sering ditindas dan dihina (bnd. Luk. 6:20 dan Mat. 5:3). Demikian juga kepada orang-orang tawanan akan diberitakan bahwa mereka akan dibebaskan. Kepada orang-orang buta (secara badaniah atau rohaniah) akan diberitakan bahwa mereka akan melihat, sedang orang-orang yang tertindas akan dibebaskan. ${ }^{20} \mathrm{Hal}$ ini menunjukkan bahwa Yesus pun berpihak pada mereka termasuk juga orang-orang miskin dan mengangkat derajat hidup mereka dengan berkata: berbahagialah kamu yang miskin..., berbahagialah hai kamu yang sekarang ini lapar (band. Pasal 6:20; 21). Istilah "berbahagialah" (Yun. Makariosberartiselamat, mujur, beruntung,dipakai untuk menyatakan kepada seseorang bahwa kita bergirang hati karena keadaannya yang menggirangkan itu. Orang-orang Yunani mempergunakan untuk memuji orang tua dengan anak-anaknya yang baik tingkah lakunya, atau orang-orang yang berada dengan kekayaan mereka atau misalnya seseorang yang mendapat kehormatan dan nama karena perbuatan-perbuatannya yang gagah berani. Juga di kalangan orang-orang Yahudi orang-orang disebutkan berbahagia apabila mereka diberkati Allah dengan dianugerahkan anak-anak atau apabila mereka mengalami keberuntungan.Sebab keselamatan (kesejahteraan) itu menurut mereka bukanlah 
hanya bersifat rohani, tetapi merangkum badan dan jiwa, yang lahiriah dan yang batiniah, yang jasmaniah dan yang rohaniah.

Dalam perjanjian Baru dapat dikatakan, bahwa seluruh keselamatan itu disimpulkan dalam istilah "Kerajaan Allah" (terwujudnya kekuasaan-Nya). Hidup dengan selamat dan bahagia ialah hidup sebagai warga Kerajaan Allah, yakni hidup "dekat kepada Allah", dengan mengasihi dan melayani Allah serta sesama manusia. Sebab itu dalam Perjanjian Baru kita dapati suatu penilaian yang berlawanan dengan penilaian di dunia ini. Misalnya: bukan tentang orang-orang kaya dikatakan bahwa mereka berbahagia atau beruntung, tetapi tentang orangorang miskin.

Dalam Perjanjian Baru Allah juga memerintahkan umat-Nya untuk menunjukkan perhatian yang mendalam kepada orang miskin dan kekurangan.Sebagian besar pelayanan Yesus adalah kepada orang miskin dan yang kurang beruntung didalam masyarakat Yahudi yang kelihatannya tidak dipedulikan orang, seperti meteka yang tertindas (Luk 4:18-19), orang Samaria (Luk 17:11-19), orang yang berpenyakit kusta (Mat 8:2-4; Luk 17:11-19), para janda (Luk 7:11-15) dan sebagainya.

Yesus beranggapan dan mengharapkan umat-Nya akan memberi dengan murah hati kepada orang miskin dan serba kekurangan (lih. Mat 6:1-4). Yesus sendiri melakukan apa yang diajarkan-Nya, dengan senantiasa membawa pundipundi yang digunakan untuk memberi kepada orang miskin (Yoh 12:5-6; 13:29). Lebih dari satu kali Ia memerintahkan orang yang mau menjadi pengikut-Nya untuk memperhatikan orang miskin, menolong mereka dan memberi mereka uang (Mat 19:21; Luk 12:33; 14:12-14, 16-24; 18:22). Pemberian itu tidak dipandang sebagai bersifat pilihan oleh Yesus; sebenarnya, salah satu tuntutan-Nya untuk memasuki kerajaan-Nya yang kekal. ${ }^{21}$

Menurut Lukas, orang-orang miskin adalah mereka yang tidak dapat memegahkan sesuatu kepunyaan mereka, baik dalam hal jasmani maupun rohani(misalnya kesalehan yang hanya dalam melaksanakan Taurat). Mereka adalah orang-orang yang hanya dengan rendah hati dapat berharap akan pertolongan Allah. ${ }^{22}$ Dan dilanjutkan dengan ajaran Yesus ketika berkhotbah di 
kaki bukit sebagai ajaran yang revolusioner dan radikal pada cerita selanjutnya ayat 27-35.Dimana teks ini berkisar pada suruhan (perintah) untuk mengasihi musuh.

Hal lain juga yang ditunjukkan Yesus adalah keberpihakan diri-Nya pada orang yang lemah dan tidak berdaya karena penyakit dan dikucilkan dalam masyarakat bahkan dijauhkan dari pemukiman rakyat karena dianggap mendatangkan kutuk, misalnya orang yang sakit kusta (pasal 5: 12-16) dan peristiwa penyembuhan orang lumpuh, yang dapat disebutkan sebagai orangorang yang tidak berdaya (pasal 5:17-26). Orang-orang yang menderita penyakit kusta ini oleh orang-orang Yahudi didiskriminasi pada waktu itu. Mereka dikucilkan dari masyarakat dan mereka dilarang untuk diikutsertakan dalam ibadah dan upacara-upacara keagamaan. Sebab orang-orang ini dianggap sebagai orang-orang yang najis, yang tidak boleh lagi berhubungan dengan Tuhan dan dengan sesamanya manusia.

Diskriminasi itu bukan hanya berdasarkan ketakutan akan penularan, tetapi latar belakangnya terdapat juga terutama dalam agama dan adat. Penyakit ini sering dianggap di kalangan orang sebagai hukuman Allah karena dosa-dosa tertentu. Dalam prakteknya di kalangan orang Yahudi peraturan-peraturan mengenai pasien-pasien itu memang agak diperlunak; orang-orang sakit tersebut tidak boleh masuk ke Yerusalem, tetapi boleh misalnya ke kota-kota lain; dengan syarat-syarat teretntu pernah juga mereka boleh turut menghadiri kebaktian dalam rumah ibadat. Diskriminasi itu tetap membuat orang-orang penyakit kusta ini merasa dirinya sebagai orang-orang yang hina. ${ }^{23}$

Dengan demikian, dalam hal ini Yesus menunjukkan sikap pluralis-Nya yang secara tidak langsung mendobrak larangan-larangan sosial untuk membantu orang-orang yang disingkirkan ini. Bahkan keterlibatan Yesus itu ditunjukkan secara langsung dengan menyentuh (Lukas memakai kata "menjamah") tangan orang yang sakit itu, bukan berdiri dari kejauhan seperti seorang yang takut ketularan penyakit. Ini juga menunjukkan bahwa Yesus lebih mengedepankan unsur perikemanusiaan jauh lebih tinggi dibandingkan dengan aturan-aturan legal keagamaan. Yesus mengenal betul adat istiadat orang-orang Yahudi, karena 
memang Ia seorang Yahudi asli yang dibesarkan dalam ruang lingkup keyahudian. Dalam batas tertentu, Yesus juga menghormati dan bahkan menjalani adat-istiadat tersebut, namun sikap hormat dan ketaatan-Nya itu tidak dilaksanakan dalam semangat legalistis yang kaku.

Dan dilanjutkan dengan peristiwa pelayanan Yesus kepada beberapa orang Yakni: Perwira di Kapernaum ${ }^{24}$ (pasal 7:1-10), kebangkitan anak muda di Nain ${ }^{25}$ (pasal 7:11-17), Kebangkitan anak Yairus dan penyembuhan seorang perempuan yang sakit pendarahan (pasal 8:40-56). Dengan tidak mengesampingkan pelayanan Yesus yang satu dengan yang lain maka pada uraian ini penulis ingin mengedepankan pelayanan yang dilakukan Yesus terhadap anak Yairus dan seorang perempuan yang sakit pendarahan, yang menurut penulis sangat bersentuh dengan sikap pluralis yang ditonjolkan Yesus dalam Injil Lukas ini. Dimana, dua pelayanan sekaligus dalam satu perjalanan menuju ke rumah si Yairus yang lalu dilambat-lambatkan oleh suatu insiden yang ditimbulkan oleh seorang perempuan.

Kisah tentang perempuan itu terdapat dalam ayat 43-48, Lukas memakai bahan Markus, (Markus 5:26), dengan panjang lebar diberitakan tentang pengalaman-pengalaman pahit yang diderita perempuan ini dari pihak tabib-tabib: ia telah mengalami banyak susak dari banyak tabib, dan telah menghabiskan segala miliknya untuk itu, tetapi tanpa hasil; bahkan kesehatannya makin bertambah parah. Agaknya, perempuan itu telah mendengar tentang Yesus dan dalam hatinya telah timbul kepercayaan bahwa Yesus dapat menyembuhkan dia. Tetapi sifat penyakitnya membuat dia malu, lagipula menurut hukum agama, perempuan itu dianggap najis karena penyakit itu (Imamat 15). Sebab itu ia tidak berani muncul didepan umum menghadap Yesus, tetapi dengan diam-diam ia mendesak dari belakang dan menerobos orang banyak itu (Markus 44).

Tampaknya pada ayat 49-56, Yesus lebih memperhatikan nasib perempuan yang najis itu daripada anak perempuan Yairus, kepala rumah ibadat yang terhormat itu. Lagi-lagi perhatian Yesus kepada perempuan dan orang-orang yang najis yang dikucilkan dan tidak dianggap sama sekali dalam realita sosial bersama bangsa Yahudi. Dengan demikian Lukas menampilkan Yesus sebagai 
orang yang memiliki kepedulian begitu tinggi terhadap mereka yang berada dalam kondisi tidak beruntung, baik karena kemiskinan maupun karena penyakit.

Sikap pluralis Yesus yang lain yang ditonjolkan oleh Lukas adalah bergaul dengan pemungut cukai dan orang berdosa (pasal 5:27-32). Pada pasal ini diceritakan tentang seorang Lewi pemungut cukai yang mengikut Yesus.Tentang siapa Lewi ini tidaklah jelas. ${ }^{26}$ Meskipun kekuasaan pusat ada pada pemerintah Romawiakan tetapi pada pelaksanaan tugas ada pendelegasian tugas dan wewenang kepada alat-alat pemerintahan. Untuk mengurusi bidang keuangan diberikan kekuasaan kepada orang-orang Yahudi untuk menarik pajak. Agar dapat menjadi pemungut cukai, seseorang harus membayar sejumlah besar uang yang diambil dari pajak bangsa Israel kepada pemerintah Romawi.Walaupun sudah ada tarif pajak yang ditetapkan tetapi tanpa pengawasan yang ketat mudah saja bagi para pemungut cukai untuk menarik uang dari rakyat lebih banyak dari yang seharusnya diberikan. ${ }^{27}$

Itulah sebabnya pemungut cukai menjadi kelompok yang tidak disukai bahkan dibenci oleh orang-orang Yahudi.Lebih dari itu, mereka dalam masyarakat disamakan dengan orang-orang berdosa dan tidak mengenal Allah.Ayat 30 dalam pasal ini menggambarkan sebuah kata-kata penghinaan yang lazim digunakan atau dipakai oleh para pemuka Yahudi yakni pemungut cukai dan orang berdosa.Akan tetapi kelompok inilah yang menjadi perhatian dalam Injil Lukas dimana, Injil ini mencatat tentang Yesus yang mau makan bersama-sama dengan para pemungut cukai dan orang berdosa.

Pada ayat 29-32 dalam pasal ini, diceritakan bahwa seakan-akan Lewi mau merayakan dan meresmikan perubahan yang telah terjadi dalam hidupnya: ia mengadakan perjamuan besar sebagai tanda kehormatan dan terima kasih kepada Yesus. Pada kesempatan itu ia mengundang juga banyak dari rekan-rekannya dan kenalan-kenalan. Kita tahu bahwa makan bersama-sama adalah tanda persekutuan yang erat.Jadi kehadiran Yesus dan para murid-Nya pada perjamuan itu menimbulkan penghinaan dan kemarahan di pihak orang-orang Farisi dan ahliahli Taurat di kalangan mereka. ${ }^{28}$ 
Sikap pluralis lain yang ditunjukkan Yesus ialah realita hidup orang Samaria misalnya (pasal 10:25-37) oleh orang Yahudi mereka adalah orang-orang yang dianggap kafir dan tidak layak untuk mendapatkan keselamatan, dimarginalkan dalam kondisi kemasyarakatan, yang lalu berdampak pada kesenjangan hidup sosial yakni hubungan sosial antara orang Yahudi dengan orang lain, malah diberi status yang lebih baik dan layak oleh Yesus. Yesus pun senantiasa dilukiskan sebagai yang berada didalam suasana konflik dengan para pemuka agama Yahudi dan bahkan pengikut-Nya pun akhirnya harus memisahkan diri dari agama Yahudi.

\section{Relevansi Sikap Pluralis Yesus dalam Praktik Hidup Orang Kristen di Maluku}

Keadaan di Maluku berangsur-angsur membaik tetapi tetap saja menjadi sebuah tanda tanya yang mesti di jawab bagi semua lapisan masyarakat Maluku. Hidup secara berdampingan antara golongan yang satu dengan golongan yang lain walaupun mulai terlihat, namun masih dalam keadaan rasa takut dan curiga ketika saling ketemu. Sebagian orang masih merasa cemas dan was-was ketika berada di tempat yang komunitasnya mayoritas atau menunjukkan ia berbeda dengan komunitas tersebut. Dengan demikian cara hidup yang dituntut adalah bagaimana mempraktekan hidup berdampingan tanpa rasa curiga. Dapat hidup secara harmonis antara seorang dan/atau kelompok dengan saling menghargai, mengintrospeksi diri sendiri dengan melakukan sesuatu yang sesuai, dapat bersama-sama tanpa melihat diri sendiri yang lebih baik dan orang lain tidak. Hidup berdampingan dan bermasyarakat harus ditegakkan dalam segala aspek kehidupan dan melihat orang lain bukan sebagai musuh.

Dalam konteks keberagaman di Maluku, dengan pengalaman konflik yang dialami pada beberapa waktu yang lalu, serta dengan melihat sikap pluralis Yesus yang telah diuraikan dalam baba-bab sebelumnya, maka sebenarnya kitab Lukas mesti dibaca secara kritis dan terbuka serta mesti disikapi secara serius dalam praktek hidup bermasyarakat dan berdampingan. Hal pertama yang mesti disikapi dalam praktik hidup bersama sesuai dengan apa yang ditunjukkan Yesus 
karena daripada-Nya kita belajar ialah sikap yang menyatakan kasih kepada orang lain.

Yesus menunjukkan sikap-Nya yang pluralis dapat dikatakan bahwa hal yang mendasarinya ialah kasih, kasih yang melintasi batas-batas sosial, tradisi bahkan agama (golongan, ras, agama dan budaya) yang lalu menembusi jurang pemisah antara "aku" dan "engkau". Dengan demikian kasih yang mesti dinyatakan adalah kasih yang bukan sebatas memenuhi kehadiran di gereja atau dengan mengadakan ritual-ritual pada tempat-tempat ibadah atau gereja, tetapi lebih daripada itu, dengan menunujukkan sikap yang nyata dalam praktik orang Kristen.Dalam sikap praktik orang Kristen, bahwa hal ini mesti menjadi bagian yang selalu melekat dan tidak boleh dilepaskan dalam menunjukkan dan memeprtanggungjawabkan identitas kekristenannya dalam hidup bersama dalam sebuah keberagaman. Sikap yang menyatakan kasih kepada orang lain diwujudkan pada mengganggap orang lain adalah sama-sama manusia yang juga mendapat porsi yang benar dalam relasi itu dengan tidak membeda-bedakan bahkan sampai pada membuat gap (yang kaya dan yang miskin, yang benar dan yang salah, yang berdosa dan yang tidak berdosa, yang lemah dan yang kuat) yang berdampak pada mendiskriminasikan orang lain. Sikap menyatakan kasih kepada orang lain dengan turut merasakan atau berempati dengan orang itu. Berempati dengan kesusahan orang lain misalnya, yang lalu membuat kita seakanakan yang mengalami kesusahan itu.

Menunjukkan sikap kasih kepada orang lain dalam praktik hidup orang Kristen memang tidak dapat dipungkiri bahwa untuk melakukannya adalah hal yang sangat sulit, membutuhkan waktu dan pengorbanan dari kita. Tetapi itu sebuah resiko yang mesti dijalani dengan kerelaan dan ketulusan dalam hidup keberagaman.Baiklah kita belajar dari seekor keledai yang dipakai sebagai alat untuk menunggangi orang yang dirampok (dalam kisah orang Samaria yang murah hati).Hal ini menunujukkan bahwa seekor binatang saja bisa dipakai sebagai alat untuk membantu manusia yang kesusahan apalagi kita sebagai manusia yang adalah paling mulia di antara segala mkhluk di dunia yang Allah ciptakan. Manusia adalah ciptaan Allah yang terakhir dari semua proses 
penciptaan, tetapi bukanlah berarti manusia tidak penting justru itulah, Allah menghargai manusia. Manusia sangat berharga dibandingkan dengan hewan. Dengan demikian, Lukas mengedepankan sikap pluralis Yesus yang dijadikan contoh atau panutan untuk bersama kita melakukan atau menyikapinya sebagai bagian refleksi iman kita manusia kepada Allah dalam relasi dengan sesama kita baik manusia dan juga makhluk ciptaan yang lain.

Untuk mengimplementasikan kasih itu dalam realita masyarakat yang majemuk, maka beberapa tawaran pemikiran yang dikedepankan oleh Ruhulessin dalam rangka menjembatani fungsi dan peran masing-masing agama dalam menjalin hubungan kerjasama antar agama. Agenda-agenda tersebut antara lain: ${ }^{29}$

- Hormat kepada kehidupan.

Tidak ada satupun negara, bangsa rasa tahu agama yang berhak membenci, menyingkirkan, mendiskriminasikan, apalagi menghancurkan suatu minoritas yang dianggap asing karena berbeda agama, etnis atau berbeda kebudayaan.Kalau ada konflik, harus diselesaikan tanpa kekerasan dan dalam kerangka hormat kepada kehidupan dan kemanusiaan.

- Solidaritas dan keadilan.

Tidak akan ada perdamaian tanpa keadilan. Karenanya, tata ekonomi harus dibuat lebih adil.Ekonomi kerakyatan yang dibutuhkan secara adil dan merata.Semua kekuatan politik, kekuatan ekonomi, asosiasi-asosiasi sukarela, termasuk lembaga-lembaga agama, lembaga-lembaga adat, harus diarahkan untuk berfungsi dan berperan bagi kesejahteraan seluruh rakyat, dan bukan bagi kepentingan kelompok atau pribadi.Kepedulian bagi mereka yang miskin, tertindas, tersingkirkan, kelompok-kelompok yang termajinalisasi di dalam masyarakat harus menjadi tolok ukur dari tegaknya solidaritas dan keadilan.

- Toleransi dan kebenaran.

Toleransi dan kebenaran kita butuhkan untuk membangun hidup bersama yang damai. Kita harus mencari kebenaran dalam kejujuran daripada menyebarkan pandangan idiologi sempit, absolute dan ekslusif. Agamaagama tidak hanya menyebarkan kebenaran yang dapat dipercaya, tetapi 
agama-agama sendiri harus menjadi pelaku-pelaku kebenaran yang patut dipercaya.Kebenaran tidak bisa hanya dipahami melalui gagasan-gagasan, tetapi kebenaran harus terbingkai dalam tindakan-tindakan yang konkrit antarmanusia, antar pribadi-pribadi manusia.Agama-agama harus membangun komunikasi yang jujur atas dasar sikap hormat dan saling menghargai.Tanpa toleransi, saling pengertian dan penghargaan, kita tidak mungkin membangun tata kehidupan yang damai, adil, setara, penuh penghargaan dan penghormatan terhadap harkat dan martabat manusia.

- Kesamaan hak dan kedudukan

Dalam konteks bernegara, kesamaan dan kesetaraan setiap warga negara harus menjadi prinsip bersama yang utama, dimana setiap orang diperlakukan sama, tidak dikotak-kotakan atas dasar apapun yang diskriminatif, seperti agama, etnik dan atau kebudayaan. Kemanusiaan itu selalu bertumpu pada hakikat manusia sebagai ciptaan Tuhan.

- Dialog dan kerjasama kemanusiaan sebagai pilihan.

Setiap agama selalu terbuka ruang dan peluang dialog kerjasama antar pemeluk beda agama guna membangun masyarakat dengan lebih santun, damai dan berkemakmuran. Ketika hampir mustahil membangun sebuah masyarakat Maluku tanpa perbedaan keagamaan, maka dialog dan kerjasama kemanusiaan untuk kemakmuran dan kebaikan bersama menjadi pilihan sebuah kemestian sosial.Bahwa, tujuan dari dialog dan kerjasama kemanusiaan adalah bukan untuk kepentingan taktis.Hal ini bersangkut paut dengan kepedulian etis, sebab disitulah kemanusiaan berjumpa. Selain itu, ia mesti berbasis padda kebutuhan umat atau manusia, bukan pada kebutuhan lembaga. Kalau ia bermuara pada kepedulian etik, maka dialog harus menghasilkan karya-karya dan agenda-agenda riil misalnya, penagngullangan HIV Aids dan lainnya. ${ }^{30}$

Dengan demikian, apa yang ditawarkan Ruhulessin seperti yang diuraikan di atas, menunjukkan bahwa sebenarnya makna hidup yang ditampilkan Yesus sesuai dengan sikap kasih yang ditunjukkan sebagai hal yang utama menjadi 
sebuah bentuk nilai keagamaan ditengah-tengah realita kehidupan masyarakat, serta menjadi panggilan bagi setiap manusia yang hidup dalam konteks keberagaman baik agama, etnis, ras, dan budaya. Hal ini menjadi penting dan sangat relevan dalam rangka menjembatani hubungan antar agama dan antar gereja di Maluku.

Maluku, khususnya kota Ambon, pada beberapa waktu yang lalu dipercayakan menjadi tuan rumah pelaksanaan dua event nasional yakni MTQ dan Pesparawi Mahasiswa tingkat Nasional, yang sebenarnya jika dilihat dari segi penetapan wilayahnya, ini menjadi sebuah tanda kepercayaan orang lain, kota lain bahkan negara lain bahwa Maluku dengan pengalaman konflik kemanusiaan yang pernah dialaminya, sudah benar-benar aman. Seperti yang dikatakan dalam salah satu tulisan di media Koran Ambon Ekspres, ${ }^{31}$ bahwa dalam pelaksanaan Pesparawi pada tanggal 15-21 Oktober kemarin, orang Maluku yang memiliki hidup orang basudara mungkin harus belajar dari duta-duta lain daerah. Kehadiran mereka bukan hanya membawa komitmen juara, tanpa sadar, mereka memeprtontonkan toleransi hidup antar umat beragama yang begitu tinggi.Mungkin tak terjangkau oleh masyarakat Maluku.

Tak kenal perbedaan, mereka bersatu dalam kesamaan tujuan, tampil memperlihatkan kemampuan terbaik untuk dapat meraih juara. Bersatu dalam perbedaan, itulah yang harus kita pelajari setelah sekian lama masyarakat Maluku hidup dalam dimensi perbedaan dan terkotak-kotak, dan itulah yang dibutuhkan masyarakat Maluku untuk mengembalikan berbagai keindahannya, menunjukkan wajah-wajah manis di nusantara ini. Karena bersatu akan mendatangkan keharmonisan dan keselarasan, berbuah keamanan dan kenyamanan, sehingga terpupuk rasa sayang dan cinta antar sesama.

\section{PENUTUP}

Pluralisme dalam Injil Lukas yang merupakan salah satu dari keempat Injil Sinoptis memberikan perhatian bagi mereka yang miskin, yang tidak berdaya, orang-orang kecil, mereka yang tidak diperhitungkan dan mereka yang didiskriminasikan dalam masyarakat. Lukas menonjolkan sikap Yesus yang juga 
berpihak pada mereka itu. Sikap pluralis Yesus ditunjukkan bagi orang-orang miskin, mereka yang berpenyakit dan dikucilkan dan didiskriminasikan dalam relasi dengan orang lain, orang-orang berdosa, perempuan dan anak-anak yang dianggap kecil dan tidak diperhitungkan, sampai kepada mereka yang dalam kehidupan masyarakat dan berbangsa dianggap musuh. Lukas menunjukkan bentuk konkrit sikap pluralis Yesus yang menurut penulis adalah juga bagian cerita yang tidak kita temui dalam kitab-kitab Injil lainnya, yakni cerita orang Samaria yang murah hati dan ajakan untuk mengasihi musuh. Kemudian, menjadi pewartaan orang-orang Kristen dan bagi semua orang tanpa terkecuali, lewat sikap konkrit yang dinyatakan dalam kehidupan setiap hari. Menurut penulis, dalam konteks kehidupan orang-orang Maluku yang punya pengalaman konflik, sikap pluralis Yesus mesti diadopsi dalam membangun kembali kehidupan yang harmonis.

\section{Endnote :}

${ }^{1}$ John A. Titaley, Menuju Teologi Agama-agama Yang Kontekstual, (UKSW: Salatiga, 2001), hlm. 8

${ }^{2}$ John Hickdalam Ibnu Mujib dan Yance Z. Rumahuru, Paradigma Transformatif Masyarakat Dialog, Membangun Fondasi Dialog Agama-agama berbasis Teologi Humanis, (Yogyakarta: Pustaka Pelajar, 2010), hlm. 49.

${ }^{3}$ R.T. France, Yesus Sang Radikal, (Jakarta: BPK Gunung Mulia,2009), hlm. 75-77

${ }^{4}$ J.L. Ch. Abineno, Yesus dari Nazaret, (Jakarta: BPK Gunung Mulia, 2006),hlm. 48-57

${ }^{5}$ Robert R. Boehlke, Siapakah Yesus Sebenarnya?,(Jakarta: BPK Gunung Mulia, 2001), hlm. 33

${ }^{6}$ Ibid, hlm. 34-35

${ }^{7}$ Judul dan nama semacam itu tidaklah berasal dari pengarang itu sendiri, tetapi berdasarkan hadits atau tradisi: pemberitahuan seperti itu pada mulanya disimpan secar lisan; kemudian orang menuliskannya di bagian atas pada halaman naskah (yaitu pada waktu dibuat menuliskannya tulisan-tulisan itu untuk dipakai dalam jemaat-jemaat Kristen).

${ }^{8}$ Yang dimaksud dengan kitab pertama dari kedua kitab ialah Injil Lukas merupakan jilid pertama dari dua-jilid sejarah mengenai kekristenan mula-mula yang dilanjutkan dalam Kisah Para Rasul. Gaya dan jenis bahasa kedua kitab itu begitu mirip sehingga tidak ada keragu-raguan lagi bahwa keduanya merupakan hasil karya satu orang penulis.

${ }^{9}$ Teofilus, bahasa Yunani dari 'pengasih Allah', orang non yahudi,mungkin orang terkemuka dan salah seorang perwira tinggi di pemerintahan Romawi.Lihat W.R.F. Browning, Kamus Alkitab, (Jakarta: BPK Gunung Mulia,2007), hlm.441

${ }^{10}$ O.C. Edwars Jr, Injil Lukas sebagai Cerita, (Jakarta: BPK Gunung Mulia, 2009), hlm. 1

${ }^{11}$ B. J. Boland, Tafsiran Alkitab Injil Lukas, (Jakarta: BPK Gunung Mulia, 2010), hlm. 3

${ }^{12}$ John Drane, Memahami Perjanjian Baru,(Jakarta: BPK Gunung Mulia, 2003), hlm. 212

${ }^{13}$ Dalam bahasa Jerman "Quelle", yang artinya sumber. Sejarah agama Kristen mula-mula yang menyatakan bahwa mayoritasnya adalah para Sarjana yang menyatakan bahwa Markus adalah kitab Injil pertama, dimana bahwa Mtius dan Lukas menggunakan Injil Markus atau sejenisnya, 
dan sumber yang menyatakan ini disebut Sumber Q. Lihat. Norman. Perrin, The New Testament An Introduction, Second Edition, Harcourt Brace Jovanovich, (New York, 1982), hlm. 100.

${ }^{14}$ Op.Cit, Boland... hlm. 6-7

${ }^{15}$ M.E. Duyverman, Pembimbing ke dalam Perjanjian Baru, (Jakarta: BPK Gunung Mulia, 2003), hlm. 64-67

${ }^{16}$ Norman Perrin, The New Testament An Introduction, Second Edition, (Harcourt Brace Jovanovich, New York, 1982), hlm.309

${ }^{17}$ Willi Marxsen, Pengantar Perjanjian Baru: Pendekatan Kritis terhadap Masalah-masalahnya, (Jakarta: BPK Gunung Mulia, 2005), hlm. 193

${ }^{18}$ R.T. France, Yesus sang radikal: Potret manusia Yang Disalibkan, (Jakarta: BPK Gunung Mulia, 2009), hlm. 78

${ }^{19}$ Kisah Lukas mengenai pengalaman Yesus di Nazaret adalah lebih panjang-lebar daripada apa yang terdapat dalam Markus dan Matius (Mrk. 6:1-6; Mat.13:53-58). Dan meskipun Lukas tahu bahwa Yesus tidak memulai pekerjaan-Nya di Nazaret (lih.ay.23), namun ia mendahulukan kisah ini. Karena Lukas menganggap apa yang terjadi di Nazaret itu sebagai contoh yang mencirikan hidup Yesus selanjutnya, lihat B.J. Boland, Tafsiran Alkitab Injil Lukas, (Jakarta: BPK Gunung Mulia, 2010), hlm.102)

${ }^{20}$ Boland, ...., Ibid. hlm. 104

${ }^{21}$ Alkitab Penuntun Hidup Berkelimpahan,Malang: Gandum Mas), 1994, hlm. 1410-1411

${ }^{22} \mathrm{Ibid}$, hlm. 148-149

${ }^{23} \mathrm{Ibid}$, hlm. 121-122

${ }^{24}$ Kapernaum adalah Kota di pantai baratlaut Laut Galilea. Namanya yang jelas diambil dari bahasa Ibrani kefar nakhum, desa dari Nahum, yang dijadikan satu kata dalam bahasa Yunani. Kota ini menjadi tempat kediaman pemungut cukai; dan kehadiran seorang Perwira (Mat. 8:5) mungkin berarti bahwa di situ ada pos militer Romawi. Yesus memakai Kota itu sebagai markas besar-Nya untuk beberapa waktu. Itulah sebabnya Kota itu dikenal sebagai Kota-Nya sendiri (Mat. 9:1). AkhirnyaYesus mengutuk Kapernaum karena ketidakpercayaan penduduknya, dan menubuatkannya runtuh. Lihat. Ensiklopedi Alkitab Masa Kini Jilid 1, (Yogyakarta: Yayasan Komunikasi Bina Kasih, 1994),hlm. 520-521)

${ }^{25}$ Nain adalah Desa kecil yang masih mengenakan nama ini di daratan Yizreel, beberapa km sebelah selatan Nazaret, di pinggir Hermon kecil, dan umumnya diterima sebagai cerita dalam Injil. Ensiklopedi Alkitab Masa Kini Jilid 2, hlm. 120

${ }^{26}$ Tentang para pemungut cukai ini (baca pasal 3:10-14). Dalam Markus 2:14 ia bernama Lewi bin (anak) Alfeus. Sesudah cerita tentang pemanggilan Lewi ini tidak lagi dipercakapkan tentang dia. Itulah sebabnya barangkali di kemudian hari disangka bahwa Lewi ini adalah sama orangnya dengan Rasul Matius (lih.Mat.9:9 dan 10:3), dan bahwa dialah pengarang Kitab Injil yang disebut Injil Matius. Boland, ..., Op.Cit, hlm. 132

${ }^{27}$ http://id.wikipedia.org/wiki/injil_lukas, diakses tanggal 25 Agustus 2012 pukul 20:15 WIBT

${ }^{28}$ Op.Cit, Boland..., hlm. 133

${ }^{29}$ John CHR. Ruhulessin, Jelajah Pemikiran Etika Menuju Jalan Etika Kristen di Indonesia, hlm. $223-225$

${ }^{30}$ John Ruhulessin, Etika Publik: Menggali dari Tradisi Pela di Maluku Tengah, Disertasi pada Program Pascasarjana Program studi Sosiologi Agama, (UKSW: Salatiga, 2005).

${ }^{31}$ Ruang Publik: "Pesparawi Ajarkan Keindahan Hidup", Ambon, Harian Ambon Ekspres, 22 Oktober 2012. 


\section{DAFTAR PUSTAKA}

Abineno, J.L.Ch, 2006.Yesus Dari Nazaret: Suatu Uraian Historis Alkitabiah.Jakarta:BPK Gunung Mulia.

Behlke, Robert R, 2001.Siapakah Yesus Sebenarnya.Jakarta: BPK Gunung Mulia.

Boland, B.J., 2010.Tafsiran Alkitab Injil Lukas. Jakarta: BPK Gunung Mulia.

Duyverman, M.E., 2003.Pembimbing kedalam Perjanjian Baru.BPK Gunung Mulia, Jakarta.

Edwars, O.C., 2009.Injil Lukas Sebagai Cerita.Jakarta: BPK Gunung Mulia.

France, R.T., 2009.Yesus Sang Radikal: Potret Manusia Yang Disalibkan.Jakarta: BPK Gunung Mulia.

Hick, John, 1985.Problems Of Religious Pluralism. London: The Macmillan. 1982. God has many Names, Philadelphia: The New Mestminter Press.

Mujib Ibnu dan Rumahuru Yance Z., 2010.Paradigma Transformatif Masyarakat Dialog, Membangun Fondasi Dialog Agama-agama Berbasis Teologi Humanis. Yogyakarta: Pustaka Pelajar.

Peririn, Norman, 1982, The New Testament An Introduction. Second Edition, New York: Harcourt Brace Jovanovich.

Ruhulessin, John. Chr., 2005.Etika Publik: Menggali dari Pela di Maluku Tengah, Disertasi pada program Pascasarjana Program Studi Sosiologi Agama.UKSW:Salatiga Jelajah Pemikiran Etika Menuju Jalan Baru Etika Kristen di Indonesia.

\section{Kamus}

Browning,W.R.F., 2007.Kamus Alkitab.Jakarta:BPK Gunung Mulia.

Kamus Besar Bahasa Indonesia Edisi Keempat.Departemen Pendidikan Nasional, 2008.Jakarta: PT Gramedia Pustaka Utama.

Ensiklopedi Alkitab Masa Kini Jilid 1 dan 2, 1994. Yogyakarta: Yayasan Komunikasi Bina Kasih 